\title{
Pengaruh Lingkungan Belajar, Motivasi Belajar dan Kemandirian Belajar terhadap Hasil Belajar Matematika Siswa Kelas XI IPA SMAN 9 Pangkep
}

\author{
St. Nur Humairah Halim ${ }^{\text {* }}$, Rahma ${ }^{2}$ \\ 1,2 Pendidikan Matematika, FKIP, Universitas Muhammadiyah Makassar, Makassar \\ *email: humairah@unismuh.ac.id
}

\begin{abstract}
This study aims to study the influence of learning environment, learning motivation and learning independence of the learning outcomes of students of class XI IPA SMAN 9 Pangkep. This type of research is ex-post facto research. The sample in this study was class XI IPA 1 and XI IPA 2 with a total of 69 students. The results showed that the partial way is positive and significant influence of learning environment on the learning outcomes about 14\%, positive and significant influence learning motivation towards the mathematics learning outcomes about $34 \%$ and learning independence had a positive effect and significant to the learning outcomes about $32 \%$. Meanwhile, learning environment, learning motivation and learning independence had positive and significant impacts together on the mathematics learning outcomes of students of class XI IPA of SMAN 9 Pangkep with a coefficient of determination $\mathrm{R}^{2}=0.50$ that supports environmental learning, motivation learning and independent learning supports $50 \%$ of the learning outcomes of students of class XI IPA at SMAN 9 Pangkep.
\end{abstract}

Keywords: Learning Environment; Learning Motivation; Learning Independence; Mathematics Outcome

\begin{abstract}
Abstrak
Penelitian ini bertujuan untuk mengetahui pengaruh lingkungan belajar, motivasi belajar dan kemandirian belajar terhadap hasil belajar matematika siswa kelas XI IPA SMAN 9 Pangkep. Jenis penelitian ini adalah penelitian ex-post facto. Sampel dalam penelitian ini adalah kelas XI IPA 1 dan XI IPA 2 dengan jumlah total 69 siswa. Hasil penelitian menunjukkan bahwa secara parsial lingkungan belajar berpengaruh positif dan signifikan terhadap hasil belajar matematika sebesar $14 \%$, motivasi belajar berpengaruh positif dan signifikan terhadap hasil belajar matematika sebesar 34\% dan kemandirian belajar berpengaruh positif dan signifikan terhadap hasil belajar sebesar 32\%. Sedangkan secara simultan lingkungan belajar, motivasi belajar dan kemandirian belajar berpengaruh positif dan signifikan secara bersama-sama terhadap hasil belajar matematika siswa kelas XI IPA SMAN 9 Pangkep dengan koefisien determinasi $\mathrm{R}^{2}=0,50$ yang berarti lingkungan belajar, motivasi belajar dan kemandirian belajar memberi pengaruh sebesar $50 \%$ terhadap hasil belajar matematika siswa kelas XI IPA SMAN 9 Pangkep.
\end{abstract}

Kata Kunci: Lingkungan Belajar; Motivasi Belajar; Kemandirian Belajar; Hasil Belajar Matematika

\section{PENDAHULUAN}

Pendidikan merupakan suatu usaha atau kegiatan yang dijalankan dengan teratur dan terencana dengan maksud mengubah atau mengembangkan perilaku yang diinginkan guna mengembangkan diri anak didik sehingga mampu menghadapi setiap perubahan yang terjadi. Sekolah sebagai lembaga formal merupakan sarana dalam rangka tujuan pendidikan tersebut. Melalui sekolah, siswa belajar berbagai macam hal.

Belajar yang memperoleh dukungan baik dari dalam diri individu maupun dari luar individu tentunya akan mempengaruhi keberhasilan belajar siswa. Salah satu faktor dari 
luar yang berpengaruh terhadap hasil belajar matematika siswa adalah lingkungan belajar. Lingkungan belajar merupakan segala sesuatu yang mengelilingi siswa saat melakukan kegiatan belajar. Faktor Lingkungan belajar berasal dari lingkungan nonsosial dan lingkungan sosial. Lingkungan nonsosial yaitu faktor fisik yang meliputi tempat belajar, letak sekolah, alat-alat belajar, sumber belajar, kondisi bangunan sekolah, ruang kelas, kebersihan lingkungan sekolah dan fasilitas penunjang belajar, sedangkan faktor sosial meliputi lingkungan keluarga, lingkungan sosial siswa di rumah, dan lingkungan sosial sekolah. Kondisi lingkungan belajar yang mendukung seperti tersedianya fasilitas fisik belajar, tempat belajar yang nyaman, suasana yang tenang, hubungan harmonis dengan lingkungan sosial dapat memberikan dorongan kepada siswa untuk belajar matematika sehingga hasil belajar siswa meningkat. Sebaliknya apabila kondisi lingkungan belajar kurang mendukung akan menurunkan semangat belajar siswa sehingga hasil belajar siswa akan menurun (Shohih, 2015).

Selain itu yang berpengaruh dalam keberhasilan belajar siswa adalah motivasi belajar. Motivasi merupakan pendorong suatu usaha yang disadari untuk mempengaruhi tingkah laku seseorang agar tergerak hatinya untuk melakukan sesuatu sehingga mencapai hasil dan tujuan tertentu (Zamsir \& Padmi, 2015). Adanya motivasi belajar yang kuat membuat siswa belajar dengan tekun yang pada akhirnya terwujud dalam hasil belajar yang baik. Oleh karena itu, motivasi hendaknya ditanamkan dalam diri siswa agar siswa merasa senang hati untuk mengikuti pelajaran yang diajarkan oleh gurunya di sekolah. Faktor lain yang mempengaruhi hasil belajar adalah kemandirian belajar. Kemandirian belajar siswa diperlukan agar mereka mempunyai tanggung jawab dalam mengatur dan mendisiplinkan dirinya, serta mengembangkan kemampuan belajar atas kemauan sendiri. Sikap-sikap tersebut perlu dimiliki oleh siswa sebagai peserta didik karena hal tersebut merupakan ciri dari kedewasaan orang terpelajar. Siswa telah mampu belajar secara mandiri apabila telah mampu melakukan tugas belajar tanpa ketergantungan dengan orang lain. Pada dasarnya kemandirian merupakan perilaku individu yang mampu berinisiatif, mampu mengatasi masalah, mempunyai rasa percaya diri, bertanggung jawab dan dapat melakukan sesuatu sendiri tanpa bergantung pada orang lain (Mudjiman, 2007).

Berdasarkan hasil observasi di SMA Negeri 9 Pangkep pada Oktober 2018 lingkungan belajar yang kurang kondusif dan masih memiliki kekurangan dalam lingkungan belajarnya. Seperti halnya perlengkapan dalam kelas yang memuat bahan ajar dan media pembelajaran yang masih kurang memadai. Dalam lingkungan sosial pun, interaksi masih belum tampak baik antar guru dan siswa, serta pergaulan antar siswa ada beberapa yang bersifat kelompok. Selain itu juga siswa yang mudah terpengaruh terhadap teknologi sehingga siswa ada beberapa yang masih sering bolos pada jam sekolah untuk bermain game. Dari hal itu sebenarnya siswa membutuhkan motivasi yang kuat. Namun siswa menunjukkan motivasi yang berbeda-beda. Hal ini dilihat 
dengan adanya perilaku siswa yang mengerjakan pekerjaan rumah di sekolah, dan banyak yang menganggap mata pelajaran matematika itu susah, sulit dan menegangkan. Sehingga siswa kurang termotivasi untuk belajar matematika. Kesadaran akan pentingnya belajar pada siswa juga masih sangat kurang. Dilihat dari perilaku siswa yang kadang mencontek pada saat ulangan, mengerjakan tugas rumah di sekolah dan itu pun hanya mengandalkan contekan dari teman kelasnya. Itu mengakibatkan kesadaran akan kemandirian belajar siswa kurang.

Selain itu hasil wawancara dengan salah satu guru mata pelajaran matematika juga mengatakan hasil belajar matematika siswa juga masih rendah karena masih banyak siswa yang belum mencapai ketuntasan yang diberikan oleh guru yaitu 75 . Hal ini pelajaran yang dapat diserap oleh siswa masih kurang. Tentu banyak faktor yang menyebabkan ketidaktuntasan nilai mata pelajaran matematika.

Berdasarkan masalah di atas, maka peneliti tertarik untuk mengetahui pengaruh lingkungan belajar, motivasi belajar dan kemandirian belajar terhadap hasil belajar matematika siswa kelas XI IPA SMAN 9 Pangkep.

\section{METODE}

Jenis penelitian ini adalah ex-post facto yang bersifat kausalitas. Penelitian ini dilakukan di SMAN 9 Pangkep. Populasi dalam penelitian ini adalah seluruh siswa kelas XI IPA SMAN 9 Pangkep. Teknik pengambilan sampel yang digunakan adalah teknik sampling jenuh dengan mengambil seluruh anggota populasi sebagai responden atau sampel. Jadi sampel dalam penelitian ini adalah siswa kelas XI IPA1 dan XI IPA2 dengan total keseluruhan sampel yaitu 69. Instrumen yang digunakan dalam penelitian ini yaitu adalah angket dan tes. Adapun teknik analisis data yang digunakan adalah analisis statistik deskriptif dan analisis statistik inferensial yang meliputi uji prasyarat dan uji hipotesis.

\section{HASIL DAN PEMBAHASAN}

\subsection{Hasil Penelitian}

Hipotesis 1: Lingkungan belajar berpengaruh positif terhadap hasil belajar matematika siswa kelas XI IPA SMA Negeri 9 Pangkep 
Tabel 1. Koefisien Uji Regresi linear $\mathrm{X}_{1}$ terhadap $\mathrm{Y}$

\begin{tabular}{|c|c|c|c|c|}
\hline \multirow[t]{2}{*}{ Model } & \multicolumn{2}{|c|}{$\begin{array}{l}\text { Unstandardized } \\
\text { Coefficients }\end{array}$} & $\mathrm{T}$ & P Value \\
\hline & $\mathrm{B}$ & Std. Error & & \\
\hline (Constant) & 44,46 & 7,41 & 5,90 & 0,00 \\
\hline Lingkungan Belajar & 0,47 & 0,14 & 3,36 & 0,01 \\
\hline
\end{tabular}

Pada Tabel 1 dapat dilihat nilai koefisien B variabel lingkungan belajar adalah 0,47 dengan nilai $\mathrm{P}$ Value sebesar 0,01 pada taraf signifikan $\alpha=0,05$ yang berarti $P<0,05$. Hal tersebut berarti $\mathrm{H}_{0}$ ditolak dan $\mathrm{H}_{1}$ diterima, maka dapat disimpulkan bahwa lingkungan belajar berpengaruh positif dan signifikan terhadap hasil belajar matematika siswa kelas XI IPA SMA Negeri 9 Pangkep.

Hipotesis 2: Motivasi belajar berpengaruh positif terhadap hasil belajar matematika siswa kelas XI IPA SMA Negeri 9 Pangkep

Tabel 2. Koefisien Uji Regresi linear $\mathrm{X}_{2}$ terhadap $\mathrm{Y}$

\begin{tabular}{|c|c|c|c|c|}
\hline \multirow[t]{2}{*}{ Model } & \multicolumn{2}{|c|}{ Unstandardized Coefficients } & \multirow[t]{2}{*}{$\mathrm{T}$} & \multirow[t]{2}{*}{$\mathrm{P}$ Value } \\
\hline & $\mathrm{B}$ & Std. Error & & \\
\hline (Constant) & 36,86 & 5,58 & 6,60 & 0,00 \\
\hline Motivasi Belajar & 0,67 & 0,12 & 5,85 & 0,00 \\
\hline
\end{tabular}

Pada Tabel 2 dapat dilihat nilai koefisien B variabel motivasi belajar adalah 0,67 dengan nilai $\mathrm{P}$ Value sebesar 0,00 pada taraf signifikan $\alpha=0,05$ yang berarti $P<0,05$. Hal tersebut berarti $\mathrm{H}_{0}$ ditolak dan $\mathrm{H}_{1}$ diterima, maka dapat disimpulkan bahwa motivasi belajar berpengaruh positif dan signifikan terhadap hasil belajar matematika siswa kelas XI IPA SMA Negeri 9 Pangkep.

Hipotesis 3: Kemandirian belajar berpengaruh positif terhadap hasil belajar matematika siswa kelas XI IPA SMA Negeri 9 Pangkep.

Tabel 3. Koefisien Uji Regresi linear $\mathrm{X}_{3}$ terhadap $\mathrm{Y}$

\begin{tabular}{|c|c|c|c|c|}
\hline \multirow[t]{2}{*}{ Model } & \multicolumn{2}{|c|}{ Unstandardized Coefficients } & \multirow[t]{2}{*}{$\mathrm{T}$} & \multirow[t]{2}{*}{$\mathrm{P}$} \\
\hline & B & Std. Error & & \\
\hline (Constant) & 29,21 & 7,19 & 4,06 & 0,00 \\
\hline Kemandirian Belajar & 0,73 & 0,13 & 5,59 & 0,00 \\
\hline
\end{tabular}

Pada Tabel 3 dapat dilihat nilai koefisien B variabel kemandirian belajar adalah 0,73 dengan nilai $P$ Value sebesar 0,00 pada taraf signifikan $\alpha=0,05$ yang berarti $P<0,05$. Hal tersebut berarti $\mathrm{H}_{0}$ ditolak dan $\mathrm{H}_{1}$ diterima, maka dapat disimpulkan bahwa 
kemandirian belajar berpengaruh positif dan signifikan terhadap hasil belajar matematika siswa kelas XI IPA SMA Negeri 9 Pangkep.

Hipotesis 4: Lingkungan belajar, motivasi belajar dan kemandirian belajar berpengaruh positif terhadap hasil belajar matematika siswa kelas XI IPA SMA Negeri 9 Pangkep

Tabel 4. Hasil Uji Regresi Berganda

\begin{tabular}{|c|c|c|c|c|c|}
\hline \multicolumn{6}{|c|}{ ANOVA } \\
\hline$\overline{\text { Model }}$ & $\begin{array}{l}\text { Sum_of } \\
\text { Squares }\end{array}$ & $\overline{\mathrm{Df}}$ & Mean Square & $\mathrm{F}$ & Sig. \\
\hline Regression & 2639,27 & 3 & 879,76 & 22,02 & $.000^{b}$ \\
\hline Residual & 2597,02 & 65 & 39,95 & & \\
\hline Total & 5236,29 & 68 & & & \\
\hline
\end{tabular}

Berdasarkan hasil regresi ganda dengan uji $\mathrm{F}$ pada Tabel 4, diperoleh nilai $\mathrm{F}_{\text {hitung sebesar }}$ 12,445 dengan nilai signifikan 0,00 yang lebih kecil dari 0,05 sehingga hipotesis diterima. Hal ini berarti bahwa secara bersama-sama terdapat pengaruh positif lingkungan belajar, motivasi belajar dan kemandirian belajar terhadap hasil belajar matematika siswa kelas XI IPA SMA Negeri 9 Pangkep.

Nilai koefisien determinasi $\mathrm{R}^{2}$ yang merupakan besarnya sumbangan ketiga variabel bebas terhadap variabel terikat $\mathrm{Y}$ yaitu sebesar 0,50 menunjukkan sumbangan dari ketiga variabel bebas sebesar 50\% terhadap hasil belajar matematika siswa kelas XI IPA SMAN 9 Pangkep sedangkan sisanya sebesar 50\% dijelaskan oleh variabel lain yang tidak diteliti dalam penelitian ini

\subsection{Pembahasan}

\section{Pengaruh Lingkungan Belajar terhadap Hasil Belajar Matematika Siswa}

Berdasarkan hasil penelitian yang telah dilakukan, lingkungan belajar siswa memberikan pengaruh positif dan signifikan terhadap hasil belajar matematika siswa. Hal ini dilihat dari nilai $\mathrm{P}=0,01$ pada taraf signifikan $\alpha=0,05$ yang berarti $P<0,05$ sehingga dapat dikatakan bahwa dalam penelitian ini lingkungan belajar memberikan pengaruh positif dan signifikan terhadap hasil belajar matematika siswa. Dan koefisien regresi $b_{1}$ variabel lingkungan belajar bertanda positif artinya semakin baik nilai variabel lingkungan belajar maka akan semakin baik pula hasil belajar siswa. Jadi dari hasil penelitian yang dilakukan menjawab bahwa hipotesis yang diajukan diterima yaitu lingkungan belajar berpengaruh positif dan signifikan terhadap hasil belajar matematika siswa kelas XI IPA SMA Negeri 9 Pangkep. 


\section{Pengaruh Motivasi Belajar terhadap Hasil Belajar Matematika Siswa}

Berdasarkan hasil regresi sederhana yang telah dilakukan, motivasi belajar siswa memberikan pengaruh positif terhadap hasil belajar siswa. Hal ini dilihat dari nilai $\mathrm{P}=$ 0,000 pada taraf signifikan $\alpha=0,05$ yang berarti $P<0,05$ sehingga dapat dikatakan bahwa dalam penelitian ini motivasi belajar memberikan pengaruh positif terhadap hasil belajar matematika siswa. Dan koefisien regresi $b_{2}$ variabel motivasi belajar bertanda positif artinya semakin baik nilai variabel motivasi belajar maka akan semakin baik pula hasil belajar siswa. Jadi dari hasil penelitian yang dilakukan menjawab bahwa hipotesis yang diajukan diterima yaitu motivasi belajar berpengaruh positif dan signifikan terhadap hasil belajar matematika siswa kelas XI IPA SMA Negeri 9 Pangkep. Hal ini sesuai dengan hasil penelitian terdahulu yang menunjukkan bahwa perhatian orangtua, motivasi belajar dan lingkungan sosial secara bersama-sama memberikan pengaruh yang signifikan terhadap prestasi belajar matematika siswa SMP dengan sumbangan sebesar 10,6\% (Kurniawan \& Urwatul, 2014).

\section{Pengaruh Kemandirian Belajar terhadap Hasil Belajar Matematika Siswa}

Berdasarkan hasil regresi sederhana yang telah dilakukan, kemandirian belajar siswa memberikan pengaruh positif terhadap hasil belajar siswa. Hal ini dilihat dari nilai $\mathrm{P}=$ 0,00 pada taraf signifikan $\alpha=0,05$ yang berarti $P<0,05$ sehingga dapat dikatakan bahwa dalam penelitian ini kemandirian belajar memberikan pengaruh positif dan signifikan terhadap hasil belajar matematika siswa. Dan koefisien regresi b variabel kemandirian belajar bertanda positif artinya semakin baik nilai variabel kemandirian belajar maka akan semakin baik pula hasil belajar siswa. Jadi dari hasil penelitian yang dilakukan menjawab bahwa hipotesis yang diajukan diterima yaitu kemandirian belajar berpengaruh positif dan signifikan terhadap hasil belajar matematika siswa kelas XI IPA SMA Negeri 9 Pangkep. Hal ini sesuai dengan hasil penelitian terdahulu yaitu terdapat pengaruh positif kemandirian belajar terhadap hasil belajar matematika (Suhendri, 2011).

\section{Pengaruh Lingkungan Belajar, Motivasi Belajar dan Kemandirian Belajar terhadap Hasil Belajar Matematika Siswa}

Dari hasil uji ANOVA dengan regresi ganda diperoleh nilai Nilai $F=22,019$ yang dinyatakan signifikan berdasarkan nilai signifikansi $P=0,00$ yang sangat kecil $(p<$ 0,05). Persamaan regresi yang diperoleh adalah

$$
Y=9,34+0,24 X_{1}+0,45 X_{2}+0,47 X_{3}
$$

Hal tersebut menjelaskan bahwa nilai 9,34 adalah nilai konstanta yang artinya ketika variabel lingkungan belajar, motivasi belajar dan kemandirian belajar dianggap konstan 
atau tidak ada perubahan maka besarnya variabel Y (hasil belajar matematika) adalah sebesar 9,34. Dari hasil yang diperoleh dan berdasarakan tingkat keyakinan 95\% dapat dijelaskan bahwa variabel-variabel lingkungan belajar, motivasi belajar dan kemandirian belajar secara simultan berpengaruh positif dan signifikan terhadap hasil belajar matematika siswa kelas.

Adapun koefisien determinasi atau daya penjelas yang diperoleh yaitu $R^{2}=0,50$ dapat dikatakan bahwa sekitar 50\% variasi skor hasil belajar matematika siswa dapat dijelaskan secara bersama-sama dari skor lingkungan belajar, motivasi belajar dan kemandirian belajar. Dengan kata lain sekitar 50\% variasi skor hasil belajar siswa ditentukan oleh variabel-variabel yang tidak diperhatikan dalam penelitian ini. Hal ini sesuai dengan hasil penelitian terdahulu yang menunjukkan bahwa terdapat pengaruh positif dan signifikan antara motivasi belajar dan lingkungan belajar secara bersamasama terhadap prestasi belajar (Ilyas, 2014). Selain itu penelitian relevan yang lain menunjukkan bahwa terdapat pengaruh positif dan signifikan lingkungan belajar dan kemandirian belajar secara bersama-sama terhadap prestasi belajar (Shohih, 2015).

\section{PENUTUP}

Berdasarkan hasil analisis regresi, maka dapat disimpulkan sebagai berikut : (a) Terdapat pengaruh positif dan signifikan lingkungan belajar terhadap hasil belajar matematika siswa kelas XI IPA SMA Negeri 9 Pangkep dengan besar sumbangan 14\% ; (b) Terdapat pengaruh positif dan signifikan motivasi belajar terhadap hasil belajar matematika siswa kelas XI IPA SMA Negeri 9 Pangkep dengan besar sumbangan 34\%; (c) Terdapat pengaruh positif kemandirian belajar terhadap hasil belajar matematika siswa kelas XI IPA SMA Negeri 9 Pangkep dengan besar sumbangan 32\%; (d) Terdapat pengaruh positif dan signifikan lingkungan belajar, motivasi belajar dan kemandirian belajar secara bersama-sama terhadap hasil belajar matematika siswa dengan besar sumbangan sebesar 50\% sedangkan 50\% lainnya dipengaruhi oleh variabel lain yang tidak diteliti dalam penelitian ini.

Dari kesimpulan yang diperoleh, maka penulis menyarankan agar para pendidik dan stake holder terkait agar memberikan perhatian khusus berupa perbaikan dari segi sarana prasarana pada lingkungan belajar,maupun evaluasi akan motivasi belajar dan kemandirian belajar siswanya mengingat hasil penelitian menunjukkan pengaruh bersama ketiga variabel tersebut memberikan sumbangsi yang cukup baik

\section{REFERENSI}

Ilyas, Muhammad. 2014. Pengaruh Motivasi Belajar Dan Lingkungan Belajar Terhadap Prestasi Belajar Akuntansi Siswa Kelas XI IPS SMA Negeri 1 Ngaglik Tahun Ajaran 2013/2014. Skripsi. Yogyakarta: Universitas Negeri Yogyakarta. Dipublikasikan. 
Kurniawan, Didik \& Urwatul D. (2014). Pengaruh Perhatian Orangtua, Motivasi Belajar, dan Lingkungan Sosial Terhadap Prestasi Belajar Matematika Siswa SMP. Mataram: Jurnal Riset Pendidikan Matematika. Vol 1, No. 2: 176-187.

Mudjiman, Haris. (2007). Belajar Mandiri (Self-Motivated Learning). Surakarta: UNS Press.

Shohih, F. (2015). Pengaruh Lingkungan Belajar dan Kemandirian Belajar Terhadap Prestasi Belajar Akuntansi Siswa Kelas XI IPS SMA Muhammadiyah Wonosobo Tahun Ajaran 2014/2015. Skripsi. Yogyakarta: Universitas Negeri Yogyakarta.

Suhendri, H. (2011). Pengaruh Kecerdasan Matematis-Logis dan Kemandirian Belajar terhadap Hasil Belajar Matematika. Formatif: Jurnal Ilmiah Pendidikan MIPA. https://doi.org/10.30998/formatif.v1i1.61

Zamsir, La Masi \& Padmi Fajrin. (2015). Pengaruh Motivasi Belajar Terhadap Hasil Belajar Matematika Siswa SMPN 1 Lawa. Jurnal Pendidikan Matematika. Vol. 6, No 2: 170-181 